\title{
Water Flows and Nutrient Loads to the Southwest Coast of Florida - A Study
}

U.S. Department of the Interior-U.S. Geological Survey

\section{Background}

The embayments and estuaries of Florida's southwest coast are an integral part of the south Florida ecosystem. Nutrients and other constituents are transported to these coastal waters by surface water and ground-water flow from the Everglades National Park (ENP) and the Big Cypress Preserve and by longshore and offshore tidal currents. The coastal area is an essential breeding ground for many estuarine and marine species and is a popular location for wilderness recreational pursuits as well as sport fishing. The volume of flow and the loads of nutrients being discharged from the streams draining the upland areas of ENP and Big Cypress Preserve currently are unknown.

As part of Everglades restoration activities, the U.S. Army Corps of Engineers may change the volume or location of water deliveries to the ENP. Such changes could affect the volume or distribution of inflow and associated constituents that are transported into the coastal waters of southwest Florida. Proposals to change water deliveries to the Everglades National Park and efforts to improve the environmental health of Florida Bay cannot be evaluated without some understanding of the hydrologic and water-quality characteristics of tidal rivers and coastal embayments in the region.

The southwest coast of Florida is part of a wilderness area with unique hydraulic characteristics that has historically been described as the "River of Grass." Flat terrain and lack of controlled topographic information has made it difficult to define drainage divides. Low gradients, coupled with tidal effects, create complex conditions

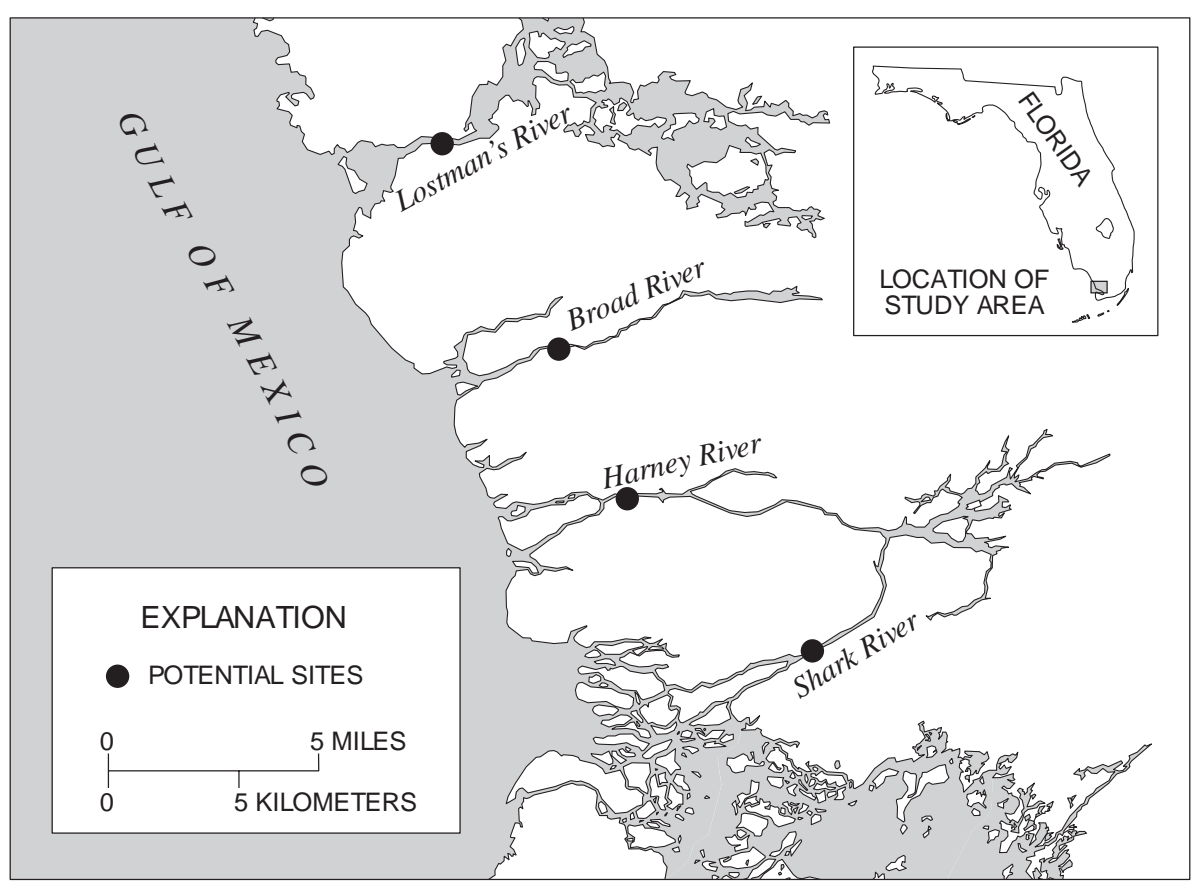

Figure 1. Location of study area.

under which to measure riverine flow. It has been almost thirty years since any effort has been made to monitor flow characteristics continuously in the area. Significant technological advancements have occurred during this time and this new technology can be applied to help obtain the information needed to make informed decisions about the future of this unique coastal area.

\section{Plan of Study}

In 1996, the U.S. Geological Survey (USGS) through the South Florida Ecosystem Initiative began a 4-year study of the flow and nutrient characteristics of two major streams that drain parts of the Everglades National Park. Efforts during the first 3 years of the study will be devoted primarily to data collection and analysis. During the latter part of the third year and during the fourth year, emphasis will be on data analysis and completion of the final report.

A reconnaissance of the southwest coastal rivers was conducted in June 1996 to identify the significant flows in the study area and to select two sites for discharge and water quality data collection. It is anticipated that the two sites will be near two sites studied by the USGS in the 1960's. Potential site locations are shown in figure 1. Coordination with personnel from the ENP, the South Florida Water Management District, and the USGS will be established early in the study to identify additional hydrologic data collection needs.

The two sites will be instrumented with an upward looking acoustic doppler current profiler (index water velocity sensor), a water-level sensor, and two specific conductance sensors. Data will be measured and recorded at 15-minute intervals. 
Data will be collected during monthly site visits by USGS personnel. Stream discharge measurements will be made monthly at the instrumented sites using an acoustic doppler current profiler. Additionally, discharge measurements will be made at other sites during the monthly visits.

Monthly discharge measurements will be used to develop discharge ratings based on the in situ sensors and discharge measurements which will provide a continuous record of river discharge. The relation of upgradient water levels and coastal net water discharge will be evaluated. Existing ENP and USGS water-level sites will be used to collect the upgradient water-level data.

Water-quality samples will be collected monthly at the instrumented sites and periodically at two noninstrumented sites along the coast. Samples will be analyzed for total and dissolved nutrients and specific conductance. Additional water-quality samples will be collected during times of extreme hydrologic conditions.

\section{Products}

Data collected for this study will include discharge, concentrations of nitrogen and phosphorus, nutrient loads, water velocity, water level, water temperature, and specific conductance from a minimum of two sites. All data will be available from the USGS Tampa office on a provisional basis pending review and approval of the final report. After approval for the final report, all data will be considered finalized and will be unconditionally released to the public.

Flow, nutrient concentrations, and nutrient load data will provide part of the basic information needed to understand the hydrologic and water-quality characteristics for a part of Florida's southwest coast. The analysis of these measurements will help characterize the current conditions for the two selected sites and explain the relation between upgradient water levels and southwest coastal stream flows, and the possible interaction between southwest coastal waters and the waters of Florida Bay. Flow and nutrient data can be used for descriptive purposes as well as serving as input to hydrodynamic and water-quality models that aid our understanding of the south Florida ecosystem.

\section{Collaboration and Partnerships}

The South Florida Ecosystem Initiative provides a unique opportunity for the USGS and the many agencies conducting studies in the area to interact. Collaboration and partnerships with those agencies are anticipated for this study.

This study will depend on a number of existing rainfall and water-level data collection stations that are maintained by other agencies. Collaboration with Everglades National Park, National Oceanic and Atmospheric Administration, and other USGS offices and divisions is anticipated to support continued data collection at these sites.

Results of this study will be useful to the Everglades National Park, National Oceanic and Atmospheric Administration, U.S. Corps of Engineers, U.S. Fish and Wildlife Service, U.S. Environmental Protection Agency, U.S. Geological Survey, Florida State Fish and Game Commission, South Florida Water Management District, universities, local agencies, and private interests who may use the data as primary or complementary information in their research, data collection activities, or computer model development.

\section{Selected References}

Fishman, M.J.,ed., 1993, Methods of analysis by the U.S. Geological Survey National Water Quality Laboratory--Determination of inorganic and organic constituents in water and fluvial sediments: U.S. Geological Survey Open-File Report 93-125, 217 p.

Schomer, N.S. and Drew, R.D., 1982, An ecological characterization of the lower Everglades, Florida Bay, and the Florida Keys: U.S. Fish and Wildlife Service, Office of Biological Services, FWS OBS-82/58.1, $246 \mathrm{p}$.

Simpson, M.R., and Oltmann, R.N., 1992, Discharge-measurement system using an acoustic doppler current profiler with applications to large rivers and estuaries: U.S. Geological Survey Open-File Report 91-487, $27 \mathrm{p}$.

Stoker, Y.E., Levesque, V.A., and Woodham, W.M., 1996, The effect of discharge and water quality of the Alafia River, Hillsborough River, and the Tampa Bypass Canal on nutrient loading to Hillsborough Bay, Florida: U.S. Geological Survey Water-Resources Investigations Report 95-4107, 69 p.

Stoker, Y.E., Levesque, V.A., and Fritz, E.M., 1996, Discharge, water-quality characteristics, and nutrient loads from McKay Bay, Delaney Creek, and East Bay, Tampa, Florida, 199193: U.S. Geological Survey WaterResources Investigations Report 954167, 47 p.

\section{by Victor $A$. Levesque}

For more information, please contact:

Victor Levesque

U.S. Geological Survey

4710 Eisenhower Blvd., B-5

Tampa, Florida 33634

(813) 243-5800 extension 167

levesque@usgs.gov 